\title{
A Tér és Társadalom 2013-ban
}

\author{
Space and Society in 2013
}

\section{CZIRFUSZ MÁRTON, TAGAI GERGELY}

\begin{abstract}
CZIRFUSZ Márton: tudományos munkatárs, MTA Közgazdaság- és Regionális Tudományi Kutatóközpont, Regionális Kutatások Intézete, Budapest; czirfusz@rkk.hu TAGAI Gergely: tudományos munkatárs, MTA Közgazdaság- és Regionális Tudományi Kutatóközpont, Regionális Kutatások Intézete, Budapest; tagai@rkk.hu
\end{abstract}

\begin{abstract}
Márton CZIRFUSZ: research fellow, Institute for Regional Studies, Research Centre for Economic and Regional Studies, Hungarian Academy of Sciences, Budapest; czirfusz@rkk.hu

Gergely TAGAI: research fellow, Institute for Regional Studies, Research Centre for Economic and Regional Studies, Hungarian Academy of Sciences, Budapest; tagai@rkk.hu
\end{abstract}

A Tér és Társadalom folyóiratban a 2011. és 2012. évi összeállítás után a 2013-as év szerzőiről és lektorairól készítettünk összefoglalót. Újdonságként néhány szempont alapján együttesen tekintünk vissza az elmúlt három évre, így a tendenciákat is megpróbáljuk kimutatni a folyóirat bezárkózására vagy nyitására vonatkozóan.

\section{A folyóirat szerzői 2013-ban}

2013-ban 72 szerzőtől jelent meg tanulmány vagy rövidebb írás a Tér és Társadalom hasábjain. Szerzőink több mint fele (39 fö) valamelyik hazai (és kisebbrészt) külföldi egyetemen vagy főiskolán végzi kutatómunkáját. Kutatótársaink közül, az MTA KRTK Regionális Kutatások Intézetéből tizenöten publikáltak tavaly az intézet hivatalos lapjában. Az MTA KRTK egyéb intézeteihez és az Akadémia további kutatóközpontjaihoz nyolc szerzőnk munkája kötödik. Egyéb kutatóintézetek, állami intézmények több munkatársának szintén jelent meg tanulmánya 2013 során a Tér és Társadalomban, de idén is akadtak a magánszférában dolgozó és nyugdíjas szerzőink.

A folyóirat szerzőinek területi megoszlása (1. ábra) 2013-ban követte az elmúlt évek trendjeit, így tavaly is a fóváros (egyetemek, kutatóintézetek, állami hivatalok stb.) és a vidéki felsőoktatási és tudományos központok adták a legtöbb szerzőt a Tér és Társadalom számára. 24 budapesti szerzőnk mellett 15 pé-

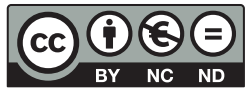


1. ábra: A Tér és Társadalom szerzőinek (munkahely szerinti) területi megoszlása, 2013 Spatial distribution of Space and Society's authors (according to workplace), 2013

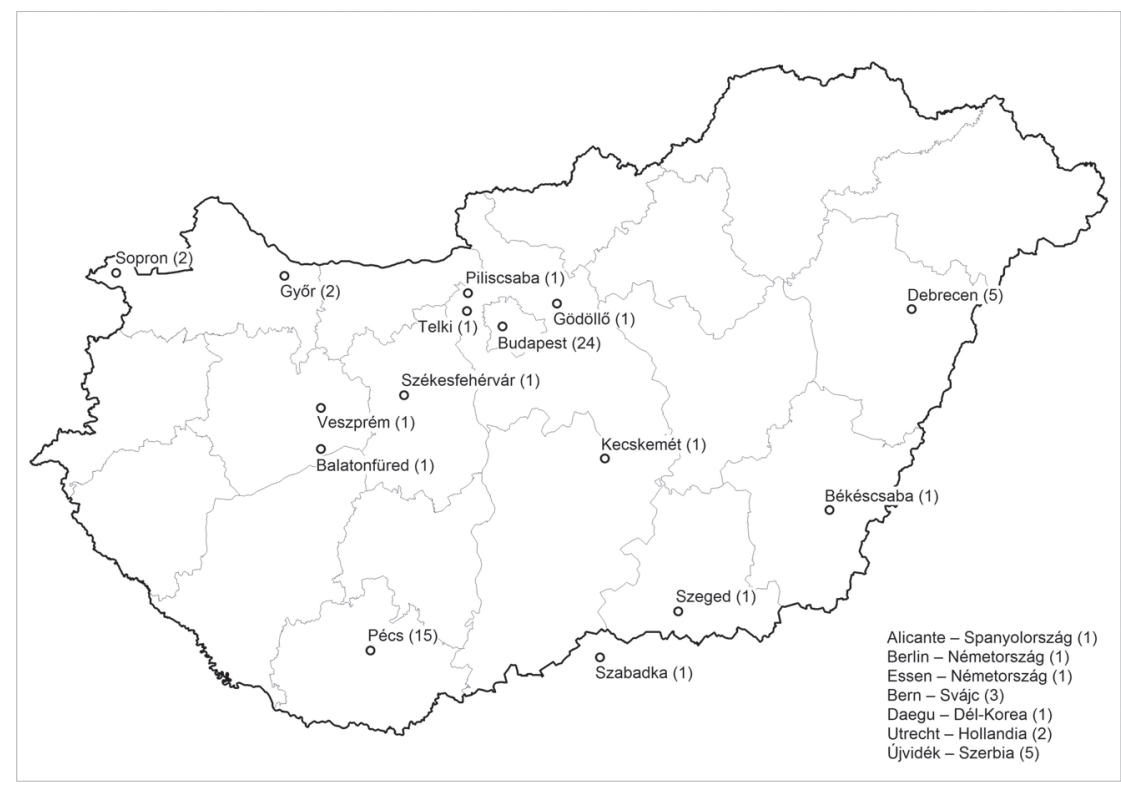

csi RKI-s és egyetemi kolléga írása volt olvasható a folyóiratban. A többi jelentősebb vidéki kutatóhelyről kisebb számban tudtunk szerzőket bevonni a tavalyi évben - legtöbbjüket (5 fó) Debrecenből. Ugyanakkor piliscsabai, telki, balatonfüredi és gödöllői szerzőink is voltak. Örömteli beszámolnunk arról, hogy 2013-ban a korábbi évekhez képest sokkal több tanulmány jelent meg külföldi szerzők tollából. Közülük ugyan a külföldi kutatóhelyeken dolgozó magyar kollégák vannak többségben, de holland, szerb és svájci nemzetiségű szerzők is hozzájárultak tanulmányaikkal a Tér és Társadalom nemzetközi nyitásához.

A korábbi évekhez hasonlóan 2013-ban is a társadalomföldrajz (18fó) és a regionális tudomány (24 fö) szakterületéről érkezett legtöbb szerzőnk. Az intézményi, akadémiai köztestületi besorolást alapul véve ezen kívül számos közgazdaság-tudományi (11 fö), szociológiai (6 fö), politikatudományi (5 fö) kötődésű szerzőnk tanulmánya jelent meg a Tér és Társadalomban. A szakmai nyitás 2013-ban is tovább folytatódott, hiszen több közelebbi vagy távolabbi társtudomány (könyvtártudomány, közigazgatás-tudomány, nyelvtudomány, pedagógia, számítástudomány, történettudomány, urbanisztika) képviselőit sikerült megszólítanunk.

Az elmúlt három évben (2011-2013) 186 szerző írása jelent meg a Tér és Társadalomban (1. táblázat). Legtöbbjük, mintegy 150 fö, egyetlen adott évben publikált a folyóiratban, de évről-évre akadtak olyan szerzőink, akik több színvonalas tanulmánnyal, érdekes beszámolóval vagy ismertetéssel gazdagították a megjelent számokat. A stabil szerzők mellett ugyanakkor az egy-egy publikációval a folyóiratban megjelenő szerzők nagy száma is pozitívumként értékel- 
1. táblázat: A Tér és Társadalom szerzői és lektorai 2011-2013 Authors and reviewers of Space and Society 2011-2013

\begin{tabular}{lrc}
\hline & Szerző & Lektor \\
\hline Mindhárom évben & 4 & 18 \\
Két évben & 31 & 39 \\
2011 és 2012 & 9 & 15 \\
2011 és 2013 & 9 & 15 \\
2012 és 2013 & 13 & 9 \\
Egy évben & 151 & 93 \\
2011 & 59 & 42 \\
2012 & 46 & 20 \\
2013 & 46 & 31 \\
\hline Összesen & 186 & 150 \\
\hline
\end{tabular}

hető, hiszen jelzi, hogy széles szakmai körben tudunk megszólítani újabb és újabb kollégákat, akik sokszor nem is visszatérő szerzőink voltak, hanem először jelent meg tanulmányuk a Tér és Társadalomban.

2013-ban a következő személyek írásai jelentek meg a folyóiratban:

$\begin{array}{lll}\text { A. Gergely András } & \text { Gábrity Eszter } & \text { Páger Balázs } \\ \text { Bajmócy Zoltán } & \text { Gábrity Molnár Irén } & \text { Palaczki Botond } \\ \text { Bartha Ákos } & \text { Gál Zoltán } & \text { Pásztor Szabolcs } \\ \text { Bögre Zsuzsanna } & \text { Göndör László } & \text { Rácz Szilárd } \\ \text { Brenner János } & \text { Grünhut Zoltán } & \text { Rátz Tamara } \\ \text { Buskó Tibor László } & \text { Horváth Áron } & \text { Régi Tamás } \\ \text { Czaller László } & \text { Horváth Gyula } & \text { Révész Gábor } \\ \text { Czinkán Norbert } & \text { Jóna György } & \text { Dušan Ristić } \\ \text { Czirfusz Márton } & \text { Jószai Attila } & \text { Schmidt Andrea } \\ \text { Csomós György } & \text { Saša Kicošev } & \text { Soóki-Tóth Gábor } \\ \text { Dankó Stefánia } & \text { Kocsis Károly } & \text { Szabó Mátyás } \\ \text { Dombi Gábor } & \text { Kovács Sándor Zsolt } & \text { Szarka Evelin } \\ \text { Dövényi Zoltán } & \text { Kovács Teréz } & \text { Szirmai Viktória } \\ \text { Dusek Tamás } & \text { Lengyel Balázs } & \text { Tagai Gergely } \\ \text { Enyedi-Tiner Klára } & \text { Leveleki Magdolna } & \text { Takács Zoltán } \\ \text { Erdei Gábor } & \text { Lux Gábor } & \text { Tátrai Patrik } \\ \text { Erőss Ágnes } & \text { Marosi Lajos } & \text { Timár Judit } \\ \text { Fábián Attila } & \text { Mezei Cecília } & \text { Tóth Balázs István } \\ \text { Faragó László } & \text { Michalkó Gábor } & \text { Emmanouil Tranos } \\ \text { Farkas Miklós } & \text { Molnár Ernő } & \text { Vámos Tibor } \\ \text { Farkas Jenő } & \text { Nagy Imre } & \text { Vápár József } \\ \text { Fekete Dávid } & \text { Németh Tamás } & \text { Váradi György } \\ \text { Filep Béla } & \text { Peter Nijkamp } & \text { Váradi Monika Mária } \\ \text { Sascha Finger } & \text { Ormosy Viktor } & \text { Doris Wastl-Walter } \\ \end{array}$




\section{A folyóirat lektorai 2013-ban}

A folyóirat színvonalának fenntartásában a lektoroké az egyik legfontosabb szerepkör: ők jelentik a szerkesztőségbe való beérkezés után a tanulmányok szigorú szakmai ellenőrzésének kulcsát. A szerkesztőség és a szerzők számára azért fontosak az észrevételeik, hogy a lapban még jobb és még jobban érthető írások jelenhessenek meg.

A lektorok bázisát ismét a regionális tudomány kulcsintézményei, azaz az MTA KRTK Regionális Kutatások Intézetében (19 fó), valamint egyetemeken és főiskolákon dolgozó kollégáink (25 fö) adták. Az RKI kutatói magukénak érzik a Tér és Társadalom folyóiratot, így lektori véleményükre többnyire számíthatunk. A tavalyi évnél jobban támaszkodtunk az MTA KRTK Közgazdaság-tudományi Intézetének és Világgazdasági Intézetének kutatóira (összesen 5 fö), akik például a világ egyes makrorégióinak gazdasági folyamatait kiválóan ismerik, a nem magyarországi témákban is otthonosak. A TéT interdiszciplináris jellegéből adódóan más MTA kutatóközpontok (elsősorban a Társadalomtudományi, valamint a Csillagászati és Földtudományi) munkatársai is lektoráltak írásokat, illetve a magánszféra és az államigazgatás is egyenként 5-6 lektort adott a folyóirat számára.

A lektorok területi megoszlásában (2. ábra) a budapesti túlsúly erősödött tavaly óta: a lektorok 57\%-a budapesti munkahelyen dolgozik, ezután Pécs kö-

2. ábra: A Tér és Társadalom lektorainak (munkahely szerinti) területi megoszlása, 2013 Spatial distribution of Space and Society's reviewers (according to workplace), 2013

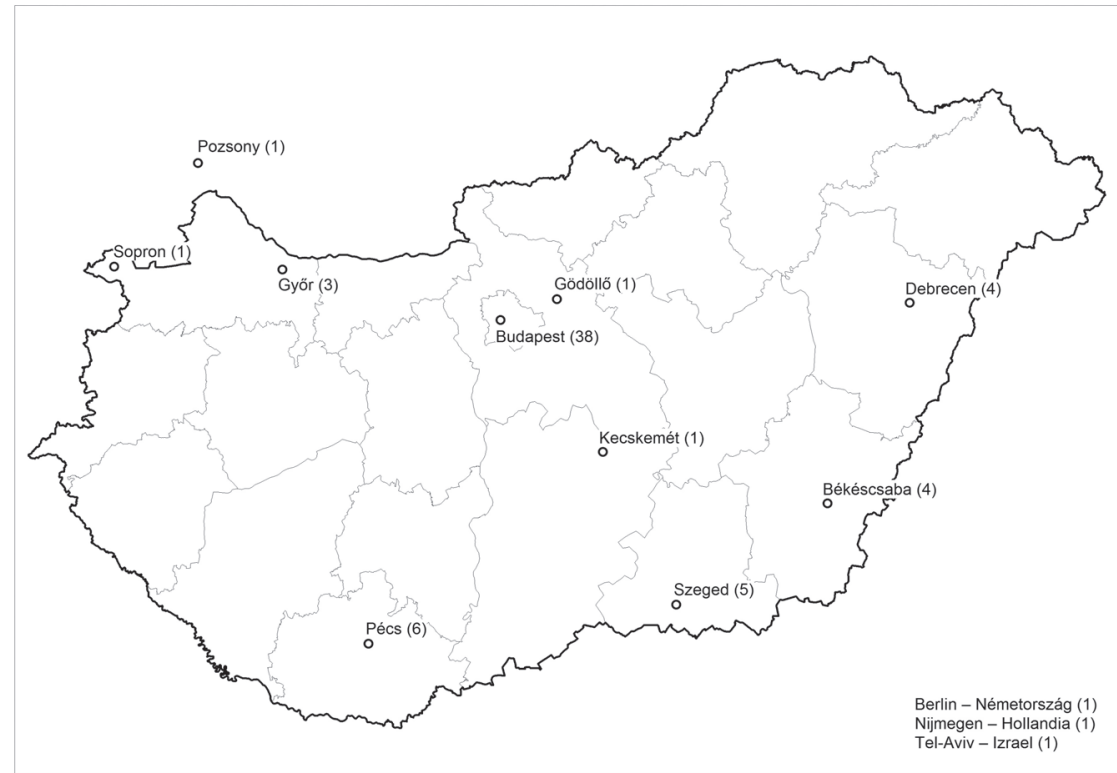


vetkezik 9\%-kal. 3-5 fő lektorált békéscsabai (MTA KRTK RKI), debreceni (Debreceni Egyetem), győri (RKI és egyetem) és szegedi (egyetem) kollégáink közül.

Ha a 2011 és 2013 közötti összesített adatokat vizsgáljuk, összesen 150-en lektoráltak kéziratokat a folyóirat számára (1. táblázat). Elmondható, hogy számíthatunk egy stabil lektori magra, akik évről évre megbízhatóan és színvonalasan véleményezik a beérkező tanulmányokat. 18-an mindhárom évben írtak lektori véleményt a folyóirat számára (kétharmaduk RKI-s kollégánk). 39 főt két évben kértünk meg cikk véleményezésére. A lektorok változó, így egyúttal bővülő körét jól jelzi, hogy 93-an csupán egy évben kaptak felkérést a szerkesztöségtől: 2013-ban például 31 olyan lektort üdvözölhettünk, akiket a 2011 eleji szerkesztőségváltás óta először szólítottunk meg.

A Tér és Társadalom angol nyelvü absztraktjainak nyelvi (és esetenként tartalmi) javításáért 2013-ban is Thomas Richersnek tartozunk köszönettel. A Tér és Társadalom számára lektori tevékenységet végző (2013 februárja és decembere között bírálatát elküldő - a 2013 januári lektorok a tavalyi összeállításunkban szerepeltek) személyekről teljes listát kívántunk összeállítani. Amennyiben saját hibánkból valakit mégis kihagytunk volna, kérjük, jelezze a szerkesztőség számára, hogy kiegészíthessük a névsort. Szerzőinknek és lektorainknak köszönjük színvonalas és felelősségteljes munkájukat!

2013. február és december között lektoraink voltak:

$\begin{array}{lll}\text { Bajmócy Zoltán } & \text { Jakobi Ákos } & \text { Schwarcz Gyöngyi } \\ \text { Baross Pál } & \text { Kádár Kriszta } & \text { Schweitzer Ferenc } \\ \text { Barta Györgyi } & \text { Koós Bálint } & \text { Sikos T. Tamás } \\ \text { Beluszky Pál } & \text { Kovács András } & \text { Sipos András } \\ \text { Bernek Ágnes } & \text { Kovács Katalin } & \text { Szabó Julianna } \\ \text { Bottlik Zsolt } & \text { Kovács Teréz } & \text { Szalavetz Andrea } \\ \text { Brenner János } & \text { Kovács Zoltán } & \text { Szalkai Gábor } \\ \text { Czirfusz Márton } & \text { Kozma Gábor } & \text { Szirmai Viktória } \\ \text { Csatári Bálint } & \text { Lengyel Imre } & \text { Szunomár Ágnes } \\ \text { Csomós György } & \text { Lukács Eszter } & \text { Tagai Gergely } \\ \text { Dusek Tamás } & \text { Lux Gábor } & \text { Timár Judit } \\ \text { Éltető Andrea } & \text { Mészáros Rezső } & \text { Tiner Tibor } \\ \text { Erő Zoltán } & \text { Michalkó Gábor } & \text { Uzzoli Annamária } \\ \text { Fábián Attila } & \text { Molnár Ernő } & \text { Váradi Monika Mária } \\ \text { Finta István } & \text { Nagy Erika } & \text { Varjú Viktor } \\ \text { Fleischer Tamás } & \text { Nagy Gábor } & \text { Varró Krisztina } \\ \text { Fleit Ernő } & \text { Nagy Terézia } & \text { Vas Zsófia } \\ \text { Gál Zoltán } & \text { Nemes Nagy József } & \text { Velkey Gábor } \\ \text { Gödri Irén } & \text { Novák Attila } & \text { Vincze Kata Zsófia } \\ \text { Győri Róbert } & \text { Ongjerth Richárd } & \text { Virág Tünde } \\ \text { Hakszer Richárd } & \text { Pálné Kovács Ilona } & \text { Völgyi Katalin } \\ \text { Hárs Ágnes } & \text { Pénzes János } & \\ \text { Hegedüs József } & \text { Rechnitzer János } & \end{array}$




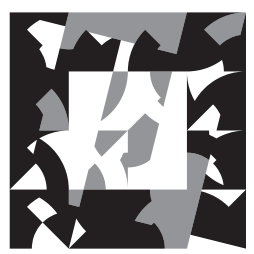

TÉR ÉS TÁRSADALOM | SPACE AND SOCIETY 